\title{
Plant Transcriptome Reprograming and Bacterial Extracellular Metabolites Underlying Tomato Drought Resistance Triggered by a Beneficial Soil Bacteria
}

\author{
Rafael J. L. Morcillo ${ }^{1,2,+}{ }^{\oplus}$, Juan I. Vílchez ${ }^{1,+}$, Song Zhang ${ }^{1,+}$, Richa Kaushal ${ }^{1}$, Danxia He ${ }^{1}$, Hailing Zi ${ }^{1}$, \\ Renyi Liu ${ }^{1}$, Karsten Niehaus ${ }^{3}$, Avtar K. Handa ${ }^{4}$ (D) and Huiming Zhang ${ }^{1, *}$ \\ 1 Shanghai Center for Plant Stress Biology, Center for Excellence in Molecular Plant Sciences, \\ Chinese Academy of Sciences, Shanghai 201602, China; rafael@sibs.ac.cn (R.J.L.M.); juan@sibs.ac.cn (J.I.V.); \\ zhangsong5861927@sdau.edu.cn (S.Z.); richa@sibs.ac.cn (R.K.); dxhe@sibs.ac.cn (D.H.); \\ zihailing@novogene.com (H.Z.); ryliu@fafu.edu.cn (R.L.) \\ 2 Institute for Water Research and Department of Microbiology, University of Granada, 18003 Granada, Spain \\ 3 Proteom-und Metabolomforschung, Fakultät für Biologie, Centrum für Biotechnologie, Universität Bielefeld, \\ 33501 Bielefeld, Germany; kniehaus@CeBiTec.Uni-Bielefeld.DE \\ 4 Department of Horticulture and Landscape Architecture, Purdue University, West Lafayette, IN 47907, USA; \\ ahanda@purdue.edu \\ * Correspondence: hmzhang@sibs.ac.cn \\ + These authors contribute equally to this work.
}

\section{check for} updates

Citation: Morcillo, R.J.L.; Vílchez, J.I.; Zhang, S.; Kaushal, R.; He, D.; Zi, H.;

Liu, R.; Niehaus, K.; Handa, A.K.; Zhang, H. Plant Transcriptome Reprograming and Bacterial

Extracellular Metabolites Underlying Tomato Drought Resistance Triggered by a Beneficial Soil Bacteria. Metabolites 2021, 11, 369. https:// doi.org/10.3390/metabo11060369

Academic Editor: Robert D Hall

Received: 22 March 2021

Accepted: 7 June 2021

Published: 9 June 2021

Publisher's Note: MDPI stays neutral with regard to jurisdictional claims in published maps and institutional affiliations.

Copyright: (c) 2021 by the authors. Licensee MDPI, Basel, Switzerland. This article is an open access article distributed under the terms and conditions of the Creative Commons Attribution (CC BY) license (https:/ / creativecommons.org/licenses/by/ $4.0 /)$.
Abstract: Water deficit is one of the major constraints to crop production and food security worldwide. Some plant growth-promoting rhizobacteria (PGPR) strains are capable of increasing plant drought resistance. Knowledge about the mechanisms underlying bacteria-induced plant drought resistance is important for PGPR applications in agriculture. In this study, we show the drought stress-mitigating effects on tomato plants by the Bacillus megaterium strain TG1-E1, followed by the profiling of plant transcriptomic responses to TG1-E1 and the profiling of bacterial extracellular metabolites. Comparison between the transcriptomes of drought-stressed plants with and without TG1-E1 inoculation revealed bacteria-induced transcriptome reprograming, with highlights on differentially expressed genes belonging to the functional categories including transcription factors, signal transduction, and cell wall biogenesis and organization. Mass spectrometry-based analysis identified over 40 bacterial extracellular metabolites, including several important regulators or osmoprotectant precursors for increasing plant drought resistance. These results demonstrate the importance of plant transcriptional regulation and bacterial metabolites in PGPR-induced plant drought resistance.

Keywords: PGPR; tomato; drought stress; Bacillus megaterium TG1-E1; transcriptome; extracellular metabolites; osmoprotectant

\section{Introduction}

Drought stress, caused by water deficit, limits the worldwide utilization of arable lands as well as crop productivity [1]. In response to drought stress, plants undergo hyperosmotic signal transduction, leading to transcriptional reprograming for the repair of stress-induced damage, the re-balancing of cellular homeostasis, and the control of growth to adapt to the water deficit condition [2].

Plants live naturally with many microorganisms including plant growth-promoting rhizobacteria (PGPR), which are beneficial soil microorganisms that can stimulate plant growth and/or increase plant resistance to various stress conditions including drought stress [3-5]. Each PGPR strain produces a complex array of extracellular metabolites, some of which are responsible for triggering beneficial effects in plants. For instance, many PGPR strains exude the enzyme ACC (1-aminocyclopropane-1-carboxylate) deaminase that reduces plant ethylene levels, as well as siderophores that facilitate root uptake of 
metal nutrients [3]. Meanwhile, bacterial exopolysaccharides improve soil aggregation and maintain soil moisture in the rhizosphere and thus can help plants survive under water deficit conditions [6].

In response to PGPR, transcriptional reprograming in plant cells plays an important role in transducing the bacterial stimuli to the enhanced plant growth and stress resistance. For instance, Bacillus amyloliquefaciens GB03 enhances Arabidopsis root iron uptake, which is supported by the transcriptional upregulation of the root $\mathrm{Fe}^{3+}$ reductase $F R O 2$ and the $\mathrm{Fe}^{2+}$ transporter IRT1, as well as by the gene induction of FIT1, a transcription activator that controls FRO2 and IRT1 gene expression [7]. Likewise, a group of plant immunity-related genes were repressed by the bacterial volatile compound diacetyl, thereby supporting the function of diacetyl in establishing a beneficial association between PGPR and plants through suppression of immune responses in phosphate-sufficient plants [8].

While PGPR provide potentially powerful tools to improve plant stress resistance in agriculture, understanding the underlying mechanisms is challenging yet crucial for successful applications. In this study, we investigated whether and how Bacillus megaterium TG1-E1, a PGPR strain isolated from a high salinity environment [9], may affect drought stress resistance in tomato plants. The drought stress-alleviating effects of TG1-E1 on two different cultivars are demonstrated, followed by the analyses of plant transcriptome and bacterial extracellular metabolites, which indicate an integrated mechanism mediated through multiple key biological processes in plants as well as bacterial osmoprotectants.

\section{Results and Discussion}

\subsection{Bacillus Megaterium TG1-E1 Increases Drought Resistance in Tomato Seedlings}

To evaluate the effects of TG1-E1 on tomato drought resistance, we studied two cultivars of tomato, Micro-Tom and Ailsa Craig, with and without bacteria inoculation. At 10 days after the drought treatment started, the drought-treated Micro-Tom plants without TG1-E1 inoculation clearly suffered from water deficit, as evidenced by the arrested growth and leaf yellowing (Figure 1A). In contrast, the drought-treated plants with TG1-E1 inoculation showed more robust growth compared to their non-inoculated counterparts (Figure 1A), demonstrating the capacity of TG1-E1 in enhancing plant drought resistance in tomato. During the period of drought treatment, soil humidity decreased similarly in the soil both with and without TG1-E1 inoculation (Figure 1B), indicating that the increased plant drought resistance was unlikely due to bacteria-dependent water retention in the soil. Under the drought conditions, inoculation with TG1-E1 increased the Micro-Tom plant's fresh weight by almost 50\% (Figure 1C). In addition, plant photosynthesis efficiency and chlorophyll contents were higher in drought-stressed plants with TG1-E1 inoculation than in those without inoculation (Figure 1D,E). Similar results were observed with the Ailsa Craig plants (Figure S1), confirming the drought stress-alleviating effects of TG1-E1 on tomato plants. The plant-beneficial effects were supported by the successful colonization of TG1-E1 to tomato roots under both mock and drought conditions (Figure S2).

\subsection{Bacillus Megaterium TG1-E1 Induces Transcriptomic Reprograming of in Tomato Plants under Drought Stress}

\subsubsection{The Overall Functional Categorization of Differentially Expressed Genes (DEGs)}

To gain insights into the mechanism for TG1-E1-increased plant drought resistance, we compared the transcriptomes between drought-stressed Micro-Tom with and without TG1-E1 inoculation. While the plants with and without TG1-E1-inoculation showed clearly contrasting phenotypes at 10 days after the drought treatment started (DAT), samples for the transcriptome analysis were harvested at 7 DAT, in order to catch the transcriptional regulation that is responsible for the downstream phenotypic changes. A total of 429 differentially expressed genes (DEGs) (Fold change $\geq 2$; $p$-values $\leq 0.05$ ) were identified, including 250 up-regulated DEGs and 179 down-regulated DEGs (Table S1). 
A

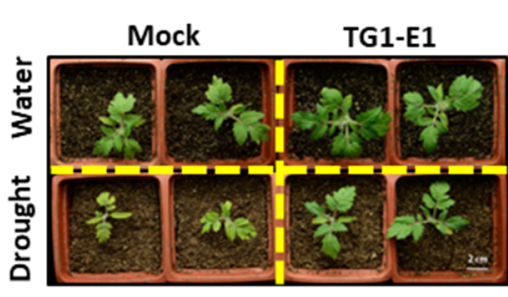

B

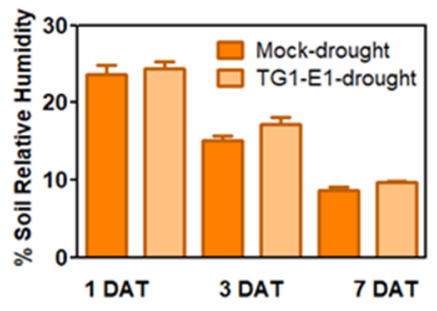

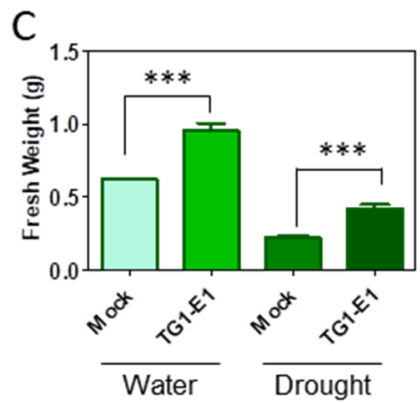

$\mathrm{D}$

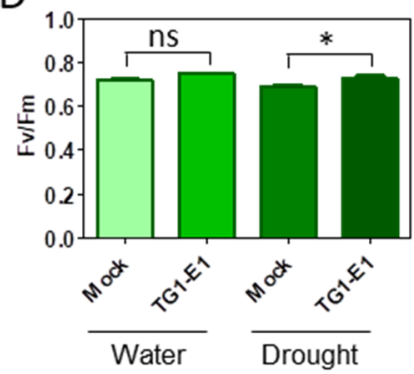

$\mathrm{E}$

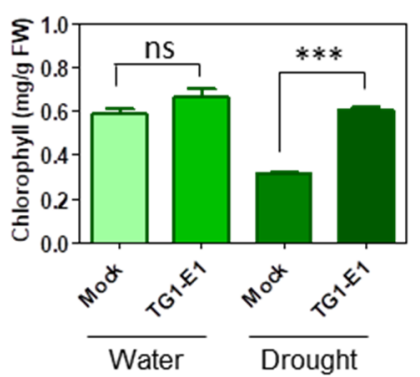

Figure 1. Bacillus megaterium TG1-E1 increases drought resistance in tomato seedlings. (A) TG1-E1 increased drought resistance in tomato (cultivar Micro-Tom) plants. Images were taken at 10 days after the drought treatment (DAT). (B) Relative humidity of the soil where tomato seedlings were grown. (C) Measurements of plant fresh weight. (D) Quantification of photosynthesis efficiency (Fv/Fm). (E) Measurements of chlorophyll contents. Results in panels (C-E) were from plants harvested at 10 DAT. The bar graphs show representative results from three independent experiments. Mean \pm SE ( $n=6$ biological replicates). Asterisks denote significant differences at $p<0.05$, Tukey's multiple comparison test $(*, * *$ and ns denote $p<0.05 ; p<0.001$ and $p>0.05$, respectively).

To obtain an overall view of TG1-E1's impacts on plant cellular functions, the TG1-E1regualted DEGs were subjected to functional categorization by using AgriGOv2 (Figure 2 and Figure S3). Major biological functional categories of the up-regulated DEGs include unknown $(27.6 \%)$, metabolism $(12 \%)$, defense and stress $(12 \%)$, signaling $(11.6 \%)$ and phytohormone metabolism and signaling (8.6\%) (Figure 2A). Meanwhile, main categories of down-regulated DEGs include unknown $(35.2 \%)$, defense and stress $(22.3 \%)$, signaling $(9.5 \%)$ and metabolism (8.4\%) (Figure 2B). Notably, the category of defense and stress accounts for $12 \%$ of up-regulated DEGs and $22 \%$ of down-regulated DEGs, whereas DEGs in this category are composed of genes encoding proteins with various functions (Figure 1A,B), indicating a complex interaction between plant responses to the biotic stimulus (TG1-E1) and the abiotic stressor (drought). In addition, the category of cell wall biosynthesis and organization was identified in both the up- and down-regulated DEGs (Figure 1A,B), indicating that TG1-E1-triggered plant drought resistance involves alterations in cell wall.

In order to identify molecular factors that potentially mediate TG1-E1-triggered plant drought resistance, we next performed DEG categorization by molecular function analysis. The results highlighted transcription factors and protein kinases among other categories, because these two categories are both abundant in DEGs which are either up- or downregulated by TG1-E1 (Figure 2C,D).

\subsubsection{DEGs Implicating Regulation Mediated through Transcription Factors}

Transcription factors are key regulators of plant responses to abiotic stress conditions including drought [10]. Genes encoding for transcription factors (TFs) accounted for 11\% of all identified DEGs (Table 1), indicating that the observed transcriptional regulation by TG1-E1 would lead to a broadened impact on the plant transcriptome later on. Therefore, the enrichment of TFs in the DEGs demonstrates a key role of transcriptional regulation in mediating TG1-E1-triggered plant drought resistance. 
A. Biological function analysis of up-regulated genes.

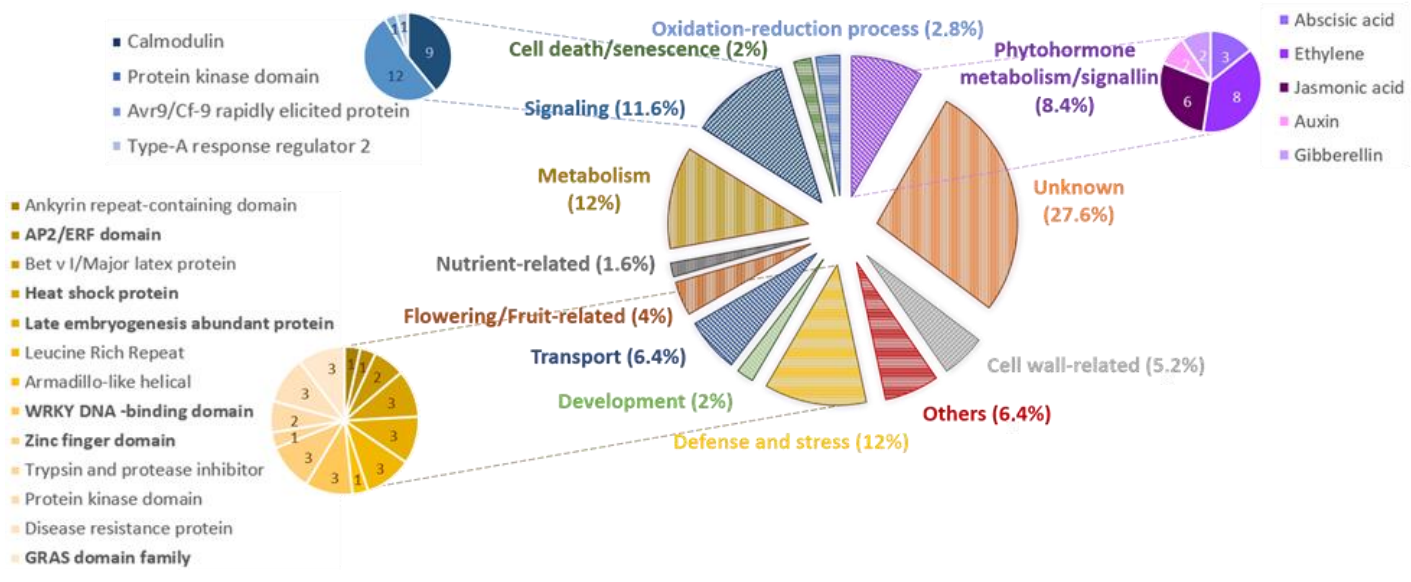

B. Biological function analysis of down-regulated genes.

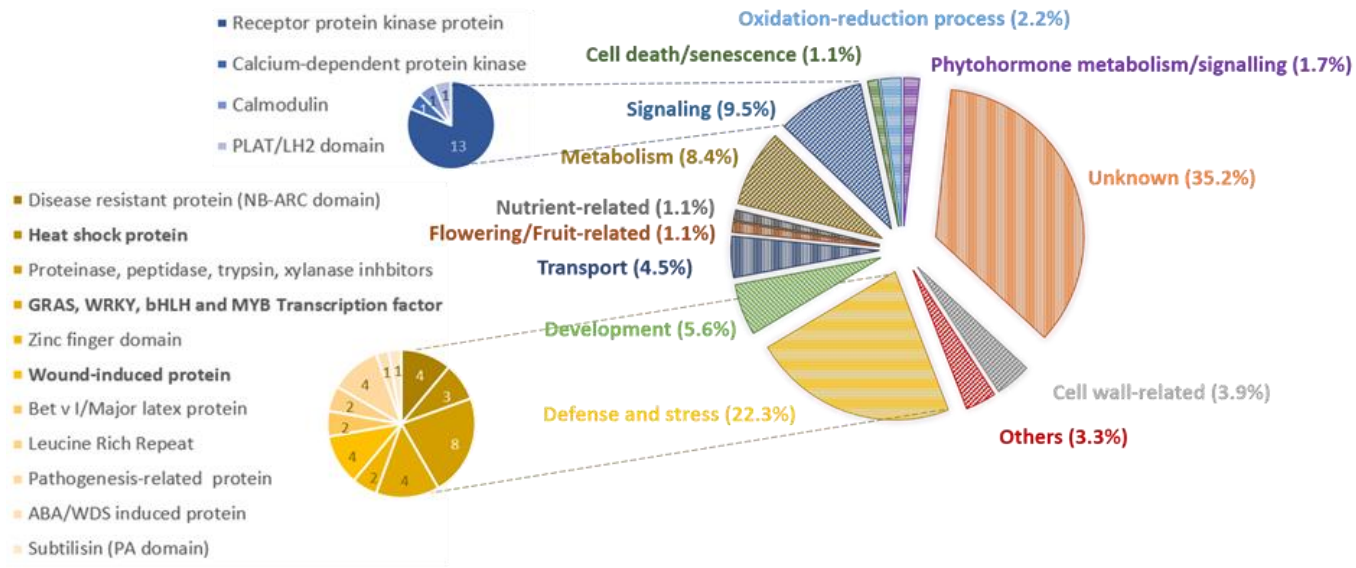

C. Molecular function analysis of up-regulated genes.

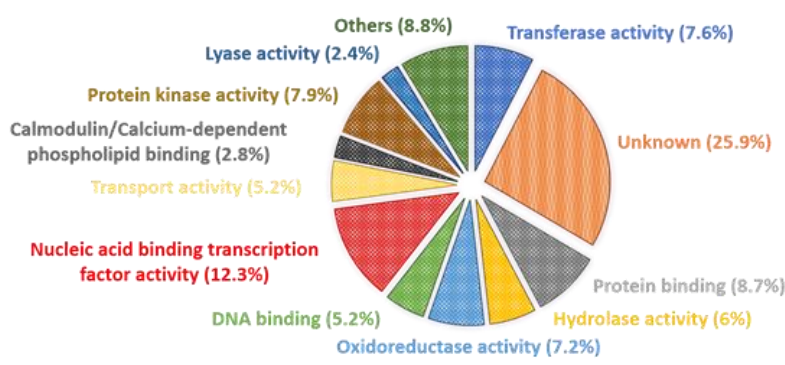

D. Molecular function analysis of down-regulated genes.

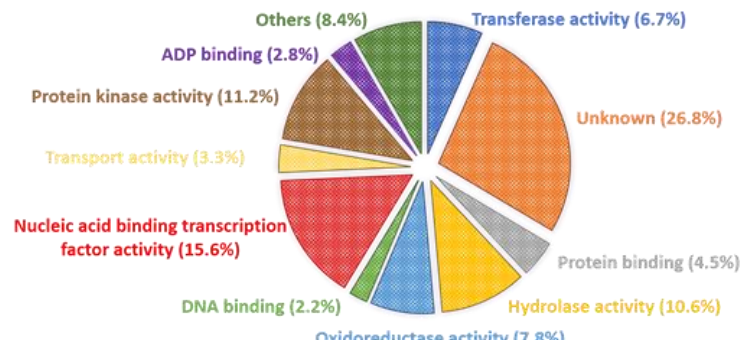

Figure 2. Functional categorization of tomato DEGs. Differentially expressed genes (DEGs) were identified by the comparison between drought-stressed plants with and without TG1-E1 inoculation. (A,B), Up- and down-regulated genes, respectively, are categorized based on their biological function. (C,D), Up- and down-regulated genes, respectively, are categorized based on their molecular function. Functional categorization was performed by using AgriGOv2. Numbers inside the diagram mean the amount of genes involved in each category. 
Table 1. Transcription factors that were transcriptionally regulated by TG1-E1 in drought-stressed tomato plants (MicroTom). The differentially expressed genes (DEGs) were defined by $\log 2$ fold-change values (LogFC) $>1$ or $<-1$ with FDR $<0.01$.

\begin{tabular}{|c|c|c|c|}
\hline Gene ID & Annotation & $\begin{array}{l}\text { Type of Nucleic Acid Binding } \\
\text { Transcription Factor Activity }\end{array}$ & $\operatorname{LogFC}$ \\
\hline Solyc07g061760.2 & Ankyrin repeats & Ankyrin repeat-containing domain & 2.29 \\
\hline Solyc08g014570.3 & PGG domain & Ankyrin repeat-containing domain & 1.06 \\
\hline Solyc06g076050.3 & Ankyrin repeats & Ankyrin repeat-containing domain & 1.04 \\
\hline Solyc05g052570.3 & Ankyrin repeats & Ankyrin repeat-containing domain & 1.11 \\
\hline Solyc05g013540.1 & AP2 domain & AP2/ERF domain & 1.07 \\
\hline Solyc02g090770.1 & AP2 domain & AP2/ERF domain & 2.79 \\
\hline Solyc08g080290.3 & AP2 domain & AP2/ERF domain & 2.58 \\
\hline Solyc08g007830.1 & AP2 domain & AP2/ERF domain & 4.48 \\
\hline Solyc06g035700.1 & AP2 domain & AP2/ERF domain & 3.41 \\
\hline Solyc08g007820.1 & AP2 domain & AP2/ERF domain & 3.02 \\
\hline Solyc10g050970.1 & AP2 domain & AP2/ERF domain & 3.01 \\
\hline Solyc01g108240.3 & AP2 domain & AP2/ERF domain & 4.22 \\
\hline Solyc10g086530.1 & GRAS domain family & GRAS domain & 1.10 \\
\hline Solyc11g012510.2 & GRAS domain family & GRAS domain & 1.28 \\
\hline Solyc12g005340.2 & GRAS domain family & GRAS domain & 1.77 \\
\hline Solyc08g080540.3 & HSF-type DNA-binding & HSF-type DNA binding & 1.64 \\
\hline Solyc02g089200.3 & SRF-type transcription factor & MADS-box & 1.95 \\
\hline Solyc05g015750.3 & SRF-type transcription factor & MADS-box & 1.67 \\
\hline Solyc01g093960.3 & SRF-type transcription factor & MADS-box & 1.04 \\
\hline Solyc06g059970.3 & SRF-type transcription factor & MADS-box & 1.03 \\
\hline Solyc02g071730.3 & SRF-type transcription factor & MADS-box & 1.09 \\
\hline Solyc08g067230.3 & K-box region & MADS-box/K-box & 2.25 \\
\hline Solyc04g081000.3 & K-box region & MADS-box/K-box & 1.42 \\
\hline Solyc05g015840.3 & SBP domain & SBP-box & 1.17 \\
\hline Solyc10g011910.3 & WRKY DNA -binding domain & Zinc finger domain & 1.84 \\
\hline Solyc03g121400.1 & Dof domain, zinc finger & Zinc finger domain & 1.10 \\
\hline Solyc06g053640.1 & Ring finger domain & Zinc finger domain & 1.85 \\
\hline Solyc10g009550.3 & WRKY DNA -binding domain & Zinc finger domain & 1.40 \\
\hline Solyc08g008280.3 & WRKY DNA -binding domain & Zinc finger domain & 1.28 \\
\hline Solyc04g015360.3 & GATA zinc finger & Zinc finger domain & 1.04 \\
\hline Solyc06g075780.2 & $\mathrm{C} 2 \mathrm{H} 2$-type zinc finger & Zinc finger domain & 1.49 \\
\hline Solyc05g051200.1 & AP2 domain & AP2/ERF domain & -1.41 \\
\hline Solyc04g007000.1 & AP2 domain & AP2/ERF domain & -1.80 \\
\hline Solyc03g119390.3 & Helix-loop-helix DNA-binding domain & bHLH domain & -1.55 \\
\hline Solyc03g034000.3 & Helix-loop-helix DNA-binding domain & bHLH domain & -1.53 \\
\hline Solyc12g049320.2 & GRAS domain family & GRAS domain & -1.34 \\
\hline Solyc02g077590.1 & Homeobox domain & HD-Zip domain & -1.34 \\
\hline Solyc05g048830.3 & Myb-like DNA-binding domain & Myb domain & -1.05 \\
\hline Solyc05g053330.3 & Myb-like DNA-binding domain & Myb domain & -1.12 \\
\hline
\end{tabular}


Table 1. Cont.

\begin{tabular}{|c|c|c|c|}
\hline Gene ID & Annotation & $\begin{array}{l}\text { Type of Nucleic Acid Binding } \\
\text { Transcription Factor Activity }\end{array}$ & $\operatorname{LogFC}$ \\
\hline Solyc12g089190.1 & Myb-like DNA-binding domain & Myb domain & -1.27 \\
\hline Solyc12g008800.2 & Myb-like DNA-binding domain & Myb domain & -1.42 \\
\hline Solyc04g076220.3 & Domain of unknown function & PPC domain & -1.30 \\
\hline Solyc05g006340.3 & WD domain, G-beta repeat & WD domain & -1.16 \\
\hline Solyc11g006450.2 & Ring finger domain & Zinc finger domain & -1.22 \\
\hline Solyc05g054650.1 & $\mathrm{C} 2 \mathrm{H} 2$-type zinc finger & Zinc finger domain & -1.24 \\
\hline Solyc05g051860.3 & zinc-finger of the FCS-type, C2-C2 & Zinc finger domain & -1.33 \\
\hline Solyc05g015850.3 & WRKY DNA -binding domain & Zinc finger domain & -1.48 \\
\hline Solyc06g008020.3 & HIT zinc finger & Zinc finger domain & -1.15 \\
\hline Solyc00g136260.1 & Ring finger domain & Zinc finger domain & -1.97 \\
\hline Solyc12g008830.2 & GATA zinc finger & Zinc finger domain & -1.44 \\
\hline Solyc03g032060.1 & Ring finger domain & Zinc finger domain & -1.11 \\
\hline Solyc12g006230.2 & Ring finger domain & Zinc finger domain & -1.77 \\
\hline Solyc08g067360.3 & WRKY DNA -binding domain & Zinc finger domain & -1.39 \\
\hline Solyc07g045180.3 & B-box zinc finger & Zinc finger domain & -1.23 \\
\hline Solyc08g082680.3 & Ring finger domain & Zinc finger domain & -1.00 \\
\hline Solyc08g067970.3 & zinc-finger of the FCS-type, C2-C2 & Zinc finger domain & -1.11 \\
\hline Solyc06g061240.3 & PLATZ transcription factor & Zinc finger domain & -1.08 \\
\hline Solyc08g065940.3 & Zinc finger C-x8-C-x5-C-x3-H type & Zinc finger domain & -1.08 \\
\hline
\end{tabular}

Among the 48 TF DEGs are 22 zinc-finger family members (Table 1), some of which have been reported as responsive to hyperosmotic stress conditions such as drought and high salinity. For example, SIWRKY75 and SIWRKY45, which are known to be repressed by drought stress [11,12], were further down-regulated by TG1-E1 in plants under the drought stress condition; meanwhile, TG1-E1 up-regulated SIWRKY53 that was reported to be highly induced by salt stress [11]. Because TG1-E1 enhances plant resistance to drought stress, the TG1-E1-dependent transcriptional enhancement (either down- or upregulation) highlights the function of these TFs in mediating plant adaptive responses to drought stress.

In addition to the zinc-finger TFs, DEGs encoding for TFs also include 10 APETALA2/ ethylene-responsive factor (AP2/ERF) domain family members with eight DEGs being upregulated, four GRAS family members with 3 DEGs being up-regulated, and seven MADSbox TFs which were all up-regulated by TG1-E1 (Table 1). These results strongly indicate that the amplification of transcriptional regulation is crucial for achieving TG1-E1-triggered plant drought resistance. The GRAS TFs play a significant role in tomato plant growth and development [13], while MADS-box TFs are key regulators of developmental plasticity in different plant species [14]. Therefore, the transcriptional regulation of these TFs provides clues to understanding how TG1-E1-treated plants adjust growth and development to adapt to the water deficit condition.

\subsubsection{DEGs Implicating Regulation of Drought-Responsive Signaling}

Protein kinases, such as calmodulin-dependent protein kinases (CDPKs), mitogenactivated protein kinases (MAPKs) and receptor protein kinases (RPKs), are important regulatory components of plant signal transduction in response to various biotic and abiotic stress conditions. In the drought-stressed plants, TG1-E1 differentially regulated a total of 38 genes encoding for several types of protein kinases (Table 2). Notably, these DEGs 
are dominated by genes encoding for RPKs, with 14 and 16 RPKs up-regulated and downregulated by TG1-E1, respectively (Table 2). The enrichment of RPKs in the kinase DEGs suggests that RPKs are important regulators of TG1-E1-triggered plant drought resistance. Meanwhile, four MAPKs (SIMAPK3, SIMAPKKK14, SlMAPKKK21, SlMAPKKK59), which have been implicated in tomato responses to environmental stress including drought [15], were up-regulated by TG1-E1 (Table 2), suggesting the important roles of these stressresponse regulators in mediating TG1-E1-triggered plant drought resistance.

Table 2. Signaling-related proteins that were transcriptionally regulated by TG1-E1 in drought-stressed tomato plants (Micro-Tom). The differentially expressed genes (DEGs) were defined by $\log 2$ fold-change values (LogFC) $>1$ or $<-1$ with FDR $<0.01$.

\begin{tabular}{|c|c|c|c|}
\hline Gene ID & Annotation & Type of Signaling Protein & $\operatorname{LogFC}$ \\
\hline Solyc11g072930.2 & Carbohydrate-binding protein of the ER & RPK & 1.74 \\
\hline Solyc06g062450.3 & Carbohydrate-binding protein of the ER & RPK & 1.44 \\
\hline Solyc02g094010.2 & Protein kinase domain & RPK & 1.58 \\
\hline Solyc09g014590.3 & Leucine Rich Repeat & RPK & 3.12 \\
\hline Solyc10g006690.3 & Protein tyrosine kinase & RPK & 1.01 \\
\hline Solyc06g007190.3 & Protein phosphatase $2 \mathrm{C}$ & ILKAP & 2.04 \\
\hline Solyc12g009550.1 & Leucine rich repeat & RPK & 1.07 \\
\hline Solyc01g005730.3 & Leucine rich repeat & RPK & 1.14 \\
\hline Solyc08g077630.3 & Protein kinase domain & RPK & 1.54 \\
\hline Solyc01g098690.2 & Leucine rich repeat $\mathrm{N}$-terminal domain & RPK & 1.23 \\
\hline Solyc05g053010.1 & Protein kinase domain & RPK & 1.59 \\
\hline Solyc07g064820.1 & Protein kinase domain & MAPK & 1.02 \\
\hline Solyc11g020230.1 & Protein kinase domain & RPK & 1.05 \\
\hline Solyc02g064980.1 & Protein kinase domain & MAPK & 3.15 \\
\hline Solyc02g090970.1 & Protein kinase domain & MAPK & 3.05 \\
\hline Solyc08g077560.3 & Protein tyrosine kinase & RPK & 1.42 \\
\hline Solyc04g074270.3 & Leucine rich repeat & RPK & 1.08 \\
\hline Solyc02g089900.1 & LysM domain & RPK & 1.07 \\
\hline Solyc06g005170.3 & Protein kinase domain & MAPK & 1.65 \\
\hline Solyc09g018280.1 & NAF domain & CDPK & 1.14 \\
\hline Solyc02g092450.3 & E1-E2 ATPase & PM-CA-ATPase & 1.28 \\
\hline Solyc02g064680.3 & E1-E2 ATPase & PM-CA-ATPase & 1.87 \\
\hline Solyc01g099370.3 & C2 domain & CaLB & 1.61 \\
\hline Solyc08g008370.3 & Development and cell death domain & CaLB & 1.66 \\
\hline Solyc03g113980.3 & Calmodulin binding protein-like & CLM & 1.05 \\
\hline Solyc06g053930.3 & EF-hand domain pair & $\mathrm{CaM}$ & 1.04 \\
\hline Solyc03g097100.1 & EF-hand domain pair & CLM & 1.10 \\
\hline Solyc11g071740.2 & EF-hand domain pair & CLM & 2.67 \\
\hline Solyc03g118810.1 & EF-hand domain pair & $\mathrm{CaM}$ & 1.38 \\
\hline Solyc03g119250.3 & Calmodulin binding protein-like & CLM & 1.99 \\
\hline Solyc06g006020.2 & Leucine Rich Repeat & RPK & -1.31 \\
\hline Solyc12g009510.1 & Leucine rich repeat & RPK & -1.13 \\
\hline Solyc11g017280.2 & Leucine rich repeat & RPK & -1.07 \\
\hline
\end{tabular}


Table 2. Cont.

\begin{tabular}{|c|c|c|c|}
\hline Gene ID & Annotation & Type of Signaling Protein & $\operatorname{LogFC}$ \\
\hline Solyc04g074020.2 & Leucine rich repeat $\mathrm{N}$-terminal domain & RPK & -1.75 \\
\hline Solyc04g009910.3 & Protein kinase domain & CDPK & -1.21 \\
\hline Solyc12g009780.1 & Leucine Rich Repeat & RPK & -1.19 \\
\hline Solyc04g074030.3 & Leucine rich repeat $\mathrm{N}$-terminal domain & RPK & -1.91 \\
\hline Solyc11g011180.2 & Leucine Rich repeat & RPK & -1.23 \\
\hline Solyc05g012430.1 & Leucine rich repeat & RPK & -1.71 \\
\hline Solyc09g090210.3 & Protein tyrosine kinase & RPK & -1.10 \\
\hline Solyc07g006770.2 & TMEM154 protein family & RPK & -1.20 \\
\hline Solyc10g076550.1 & Protein kinase domain & RPK & -1.85 \\
\hline Solyc04g074050.3 & Protein kinase domain & RPK & -1.75 \\
\hline Solyc01g067020.3 & Protein kinase domain & RPK & -1.16 \\
\hline Solyc09g075920.1 & D-mannose binding lectin & RPK & -1.10 \\
\hline Solyc08g016270.2 & Leucine rich repeat & RPK & -1.13 \\
\hline Solyc04g074000.3 & Protein tyrosine kinase & RPK & -1.64 \\
\hline Solyc08g077730.3 & MORN repeat & PIPK & -1.22 \\
\hline Solyc04g009900.3 & Protein kinase domain & PPCK & -1.27 \\
\hline Solyc12g088840.1 & EF-hand domain & CaM & -1.03 \\
\hline \multicolumn{4}{|c|}{ Malic acid related DEGs } \\
\hline Solyc04g080990.2 & Voltage-dependent anion channel & & 1.32 \\
\hline Solyc09g014610.3 & Voltage-dependent anion channel & & 1.04 \\
\hline Solyc03g119640.3 & Aluminum activated malate transporter & & 1.30 \\
\hline
\end{tabular}

RPK: Receptor-like kinase protein. ILKAP: Integrin-linked kinase-associated serine/threonine protein. MAPK: Mitogen-activated protein kinase. CDPK: Calcium/calmodulin-dependent protein kinase protein. PM-CA-ATPase: Plasma membrane $\mathrm{Ca}^{2+}$ ATPase protein. CaLB: Calcium-dependent lipid-binding protein. CaM: Calmodulim protein. CLM: Calmodulin-binding protein-like. PIPK: Phosphoinositide kinase-like protein. PPCK: Phosphoenolpyruvate carboxylase kinase.

Calmodulins receive and transduce $\mathrm{Ca}^{2+}$ signals elicited by various stressors. One of the primary responses to drought stress is an increase in the cytosolic $\mathrm{Ca}^{2+}$ concentration and subsequent transduction of $\mathrm{Ca}^{2+}$ signals that promotes appropriate cellular responses in an effort to mitigate potential damages $[2,16]$. In the drought-stressed tomato, TG1E1 increased gene expression of seven calmodulins and calmodulin-binding protein-like (CLMs) (Table 2). Notably, the CLM-encoding DEGs include SlCBP60 (Solyc03g119250), which is orthologous to $A t S I C B P 60 g$, which positively regulates plant disease resistance and drought resistance in Arabidopsis thaliana [17]. In addition, TG1-E1 also up-regulated gene expression of two calcium-dependent lipid-binding proteins and two plasma-membrane calcium-transporting ATPases (Solyc02g092450; Solyc02g064680) (Table 2), which are key regulators of stress-induced calcium transients in plants [18-20]. Together these results indicate that bacterial modulation of plant $\mathrm{Ca}^{2+}$ signaling plays an important role in mediating TG1-E1-triggered drought resistance in tomato.

TG-E1 also induced gene expression of two root C4-dicarboxylate transporter/malic acid transport protein (Solyc04g080990; Solyc09g014610) and an aluminum-activated malate transporter (Solyc03g119640) in drought-stressed tomato (Table 2). As a component of root exudates, malic acid functions in the induction of PGPR chemotaxis and the promotion of biofilm formation for better colonization [21,22]. Therefore, the induction of the malate transporter gene appears to indicate an enhancement in the association between TG1-E1 and the drought-stressed plants. 


\subsubsection{DEGs Implicating Regulation of Cell Wall Biosynthesis and Organization}

Cell wall composition and organization are modified in plants exposed to water deficit $[23,24]$ and bacterial colonization [25]. One of the primary responses of plant cell wall to drought stress is an increase in the biosynthesis of cellulose, xyloglucan and pectin to maintain cell wall integrity and cell turgor pressure, leading to continued cell growth under low water potential [26]. A group of tomato cell wall-related DEGs were identified as regulated by TG1-E1 (Table 3), including two glycosyl hydrolases (Solyc06g073750; Solyc07g006850) involved in xyloglucan metabolism, a cellulose synthase-like protein (Solyc03g097050) and a cellulose synthase-like C1-2 glycosyltransferase (Solyc02g089640) implied in cellulose biosynthesis, and a pectin esterase (Solyc09g075330) involved in pectin metabolism, thereby implying bacteria-triggered regulation of the cell wall structure in response to drought stress.

Table 3. Cell wall-related proteins that were transcriptionally regulated by TG1-E1 in drought-stressed tomato plants (Micro-Tom). The differentially expressed genes (DEGs) were defined by $\log 2$ fold-change values (LogFC) $>1$ or $<-1$ with FDR < 0.01. UDP: Uridine diphosphate; GDP: Guanosine diphosphate; NAD: Nicotinamide adenine dinucleotide.

\begin{tabular}{ccc}
\hline Gene ID & Annotation & LogFC \\
\hline Solyc06g073750.3 & Glycosyl hydrolase & 1.99 \\
\hline Solyc07g006850.2 & Glycosyl hydrolase & 1.04 \\
\hline Solyc03g115380.2 & UDP-glucose/GDP-mannose dehydrogenase & 1.78 \\
\hline Solyc02g094010.2 & Protein kinase domain & 1.58 \\
\hline Solyc03g110890.1 & Polysaccharide biosynthesis related protein & 1.13 \\
\hline Solyc09g075330.3 & GDP-fucose protein O-fucosyltransferase & 1.08 \\
\hline Solyc09g011860.3 & GDP-mannose 4,6 dehydratase & 1.69 \\
\hline Solyc12g010540.1 & Putative peptidoglycan binding domain & 1.37 \\
\hline Solyc04g005040.1 & Glycosyltransferase-like & 1.03 \\
\hline Solyc02g089640.3 & Plant invertase/pectin methylesterase inhibitor & 1.35 \\
\hline Solyc03g123620.4 & RING/Ubox-like zinc-binding domain & 1.42 \\
\hline Solyc03g097050.3 & NAD dependent epimerase/dehydratase & 1.31 \\
\hline Solyc06g074670.3 & Multicopper oxidase & -2.95 \\
\hline Solyc04g072280.3 & LysM domain & -1.23 \\
\hline Solyc03g026360.1 & -1.66 \\
\hline Solyc11g044910.2 & \\
\hline
\end{tabular}

In drought-stressed tomato plants, TG1-E1 up-regulated gene expression of several glycosyltransferases (Table 3), which may function in regulating plant cell wall polysaccharides [27]. Particularly, gene up-regulation was observed for a UDP-glucose/GDP-mannose dehydrogenase (Solyc03g115380), a GDP-fucose protein O-fucosyltransferase (Solyc09g011860), orthologous to At2g03280, and a GDP-mannose 4,6 dehydratase (Solyc12g010540), which are involved in pectin metabolism $[28,29]$, a potential glucuronoxylan 4-O-methyltransferase-like protein (Solyc03g110890), orthologous to At4g24910, implied in xylan modifications [30], and a NAD-dependent epimerase/dehydratase (Solyc06g074670) that catalyzes the conversion of UDP-D-glucuronate to UDP-D-xylose, providing nucleotide sugars for cell-wall polymers. In addition, a glycosyl hydrolase (Solyc11g044910), required for pectic arabinan modification, was down-regulated by TG1-E1. Plant polysaccharides, including arabinogalactan, pectin, and xylan, can act as environmental cues that trigger biofilm formation in certain PGPR strains and consequently support bacterial root colonization [31]. Thus, it is intriguing whether these glycosyltransferases might be involved in TG1-E1 colonization to tomato roots. 
We also found a putative matrix metalloproteinase (Solyc04g005040) that is potentially involved in the degradation and remodeling of the extracellular matrix, a cell surface continuum beyond the cell wall, which plays a vital role in cell adhesion, cell-cell communication, cell wall modification, and protection against stresses [32]. Altogether, these cell wall-related DEGs indicate that TG1-E1 might trigger modifications in plant cell wall structure and composition, which potentially contributed to TG1-E1 colonization and/or plant adaption to the altered cell turgor pressure.

\section{Hyperosmotic Stress Induces TG1-E1 Production of Extracellular Metabolites Including Potential Osmoprotectants}

To identify the bacterial factors that potentially caused the increased plant drought resistance, we collected TG1-E1 extracellular metabolites under normal and hyperosmotic stressed conditions (PEG30). Subsequently, analysis by gas chromatography coupled with mass spectrometry (GC-MS) identified 49 metabolites as being significantly altered (Fold change $\geq 1.9 ; p$-values $\leq 0.05$ ) in TG1-E1 by the hyperosmotic stress (Table 4 ).

Table 4. Extracellular metabolites released from B. megaterium TG1-E1. The ratios show metabolite levels from TG1-E1 with hyperosmotic stress (by PEG30) compared to the non-stressed condition. $\mathrm{N}=3$ biological replicates. All ratios have $p<0.05$, Student's $t$-test. MeOX: methoximated-derived compound.

\begin{tabular}{|c|c|c|c|}
\hline Compound & Mock & PEG30 & $\operatorname{LogFC}$ \\
\hline Piruvate & 0.04 & 0.14 & 1.72 \\
\hline beta-Aminoisobutiric acid & 3.99 & 11.99 & 1.59 \\
\hline acid $\alpha$-ketocaproate & 0.35 & 2.88 & 3.06 \\
\hline Urea & 20.53 & 55.66 & 1.44 \\
\hline Ethanolamine & 2.11 & 15.58 & 2.88 \\
\hline Leucine & 2666.87 & 6457.33 & 1.28 \\
\hline Succinate & 51.39 & 130.40 & 1.34 \\
\hline Glycerate & 6.04 & 16.87 & 1.48 \\
\hline Fumarate & 4.64 & 9.08 & 0.97 \\
\hline Serine & 7.56 & 34.32 & 2.18 \\
\hline Threonine & 8.33 & 50.54 & 2.60 \\
\hline beta-Alanine & 1.19 & 17.05 & 3.84 \\
\hline Glutamine & 1.51 & 6.59 & 2.13 \\
\hline Malate & 2.20 & 5.55 & 1.33 \\
\hline Cytosine & 0.05 & 0.17 & 1.72 \\
\hline L-Aspartate & 48.05 & 160.37 & 1.74 \\
\hline Ornithin-Citrullin-Arginine & 1.09 & 4.55 & 2.06 \\
\hline Xylose MeOX1 & 0.12 & 1.55 & 3.65 \\
\hline Ribose & 0.22 & 0.64 & 1.54 \\
\hline cis-Aconitate & 0.18 & 0.56 & 1.65 \\
\hline 1-Methyl-L-histidine & 0.11 & 0.49 & 2.19 \\
\hline Glycerate-3-P & 0.40 & 0.97 & 1.28 \\
\hline Citrullin-Ornithin-Arginine & 6.14 & 78.11 & 3.67 \\
\hline Citrate & 2.13 & 6.83 & 1.68 \\
\hline Isocitrate & 0.52 & 1.45 & 1.47 \\
\hline Arginine- $\mathrm{NH}_{3}$ & 8.62 & 16.92 & 0.97 \\
\hline
\end{tabular}


Table 4. Cont

\begin{tabular}{|c|c|c|c|}
\hline Compound & Mock & PEG30 & $\operatorname{LogFC}$ \\
\hline Pinitol & 0.10 & 0.28 & 1.50 \\
\hline Fructose MEOX1 & 0.09 & 0.30 & 1.78 \\
\hline Fructose MEOX2 & 0.04 & 0.12 & 1.52 \\
\hline Galactose MeOX1 & 0.11 & 0.38 & 1.84 \\
\hline Glucose MEOX1 & 0.46 & 1.46 & 1.67 \\
\hline Glucose MEOX2 & 0.04 & 0.17 & 1.99 \\
\hline Glucuronic acid MEOX1 & 0.03 & 0.13 & 2.04 \\
\hline Gluconate & 0.23 & 0.59 & 1.35 \\
\hline myo-Inositol & 7.21 & 24.71 & 1.78 \\
\hline Spermidine & 0.45 & 3.41 & 2.93 \\
\hline L-Cystathionine & 0.71 & 3.80 & 2.42 \\
\hline Tryptophan & 112.05 & 222.43 & 0.99 \\
\hline Fructose-6-P & 0.04 & 0.09 & 1.18 \\
\hline Gluconate-6-P & 0.03 & 0.13 & 2.17 \\
\hline Sucrose & 0.59 & 2.00 & 1.75 \\
\hline Trehalose & 0.33 & 0.66 & 0.98 \\
\hline Lysine & 4737.93 & 12276.77 & 1.37 \\
\hline Histidine & 193.44 & 393.00 & 1.02 \\
\hline Maleic acid & 9.10 & 2.61 & -1.80 \\
\hline Uracil & 51.66 & 13.95 & -1.89 \\
\hline Thymine & 6.94 & 0.16 & -5.46 \\
\hline 4-Aminobutyrate (GABA) & 20.49 & 3.28 & -2.64 \\
\hline
\end{tabular}

\subsection{Sugars}

TG1-E1 under hyperosmotic stress released higher levels of components of the glycolytic pathway, including glucose-6-P, fructose-6-P, glycerate-3-P, pyruvate and trehalose (Table 4). The glycolytic pathway have been related to increased levels of trehalose as an osmoprotectant molecule against drought in plants [33,34] and bacteria [35,36]. In this sense, we found an increase in trehalose upon PEG treatment, indicating that TG1-E1 might enhance plant drought tolerance by this osmoprotectant sugar.

Under the hyperosmotic stress condition, TG1-E1 also exuded higher levels of xylose, galactose, sucrose, and arabinose (Table 4). These sugars may function as a carbon reservoir, which protects microorganisms from fluctuations in water potential by enhancing water retention and regulating the diffusion of carbon sources [37,38]. Although it is unclear whether the drought-stressed plants would take in these bacteria-derived sugars, these sugars have been identified in other Bacillus strains as bacterial metabolites with a role in improving plant drought resistance [39]. In cells under dehydration stress, the hydroxyl group of cellular sugar alcohols can substitute the hydroxyl group of water to maintain the hydrophilic interactions with the membrane lipids and proteins, thereby helping the maintenance of membrane structural integrity [40].

\subsection{Amino Acids}

TG1-E1 under hyperosmotic stress accumulated a higher level of extracellular arginine, together with several other amino acids (Table 4). Arginine can be used as the substrate for producing polyamines, including spermidine, spermine and their diamine precursor putrescine, which are the major polyamines involved in drought resistance [41-43]. Inocula- 
tion of A. thaliana with Pseudomonas putida GAP-P45 caused significant fluctuations in the expression of most polyamine biosynthetic genes and cellular levels of polyamines, including putrescine and spermidine, which positively correlated with the water stress tolerant phenotype of A. thaliana in response to P. putida GAP-P45 inoculation [44,45]. In our RNAseq results, TG1-E1 significantly up-regulated the expression of several genes involved in polyamine production, including Arginine decarboxylase 1 (SlADC1; Solyc10g054440), which is a rate-limiting enzyme for the biosynthesis of putrescine and other polyamines [46,47], as well as Adenosylmethionine decarboxylase 2 (SlSAMDC2; Solyc02g089610) and S-adenosyl-lmethionine decarboxylase (Solyc02g089615) which are involved in spermidine and spermine biosynthesis [48,49] (Table 5). In contrast, the expression of genes involved in arginine biosynthesis was not affected by TG1-E1. Therefore, it is possible that TG1-E1-produced arginine may be utilized by the plants for polyamine production, thereby contributing to the bacteria-induced plant drought resistance. In addition, TG1-E1 under hyperosmotic stress exuded more spermidine than under the non-stressed condition, indicating that the plants might also directly take up bacterial polyamine to increase drought resistance.

Table 5. Transcriptional regulation of gene potentially regulated by TG1-E1 extracellular metabolites under hyperosmotic stress. The differentially expressed genes (DEGs) were defined by log2 foldchange values $(\log F C)>1$ or $<-1$ with FDR $<0.01$.

\begin{tabular}{ccc}
\hline Gene ID & Annotation & LogFC \\
\hline Solyc10g054440.2 & Pyridoxal-dependent decarboxylase & 1.46 \\
\hline Solyc02g089610.2 & Adenosylmethionine decarboxylase & 1.39 \\
\hline Solyc02g089615.1 & S-adenosyl-l-methionine decarboxylase leader peptide & 1.31 \\
\hline Solyc08g007820.1 & Dehydration-responsive element-binding protein 1E-like & 3.02 \\
\hline Solyc03g080090.3 & No apical meristem (NAM) protein & 1.08 \\
\hline Solyc07g008300.2 & Ring hydroxylating alpha subunit & 2.28 \\
\hline Solyc08g068600.3 & Pyridoxal-dependent decarboxylase conserved domain & 1.20 \\
\hline
\end{tabular}

TG1-E1 under hyperosmotic stress accumulated a higher level of extracellular glutamine (Table 4). Meanwhile, TG1-E1 up-regulated gene expression of Dehydration-responsive elementbinding protein 1E-like (DREB1a-like; Solyc08g007820) and Nam-like protein 1 (Solyc03g080090) in drought-stressed tomato. These two tomato genes are orthologous to rice OsDREB1A and OsNAC5, respectively, which are inducible by exogenous glutamine, and play positive roles in rice plant drought resistance [50-52]. Thus, it appears that the gene induction of tomato DREB1a-like and Nam-like protein 1 by bacterial glutamine also contributes to TG1-E1-triggered plant drought resistance. Consistent with a positive role of glutamine in plant drought resistance, pepper plants inoculated with Microbacterium sp. 3J1 accumulated showed increased levels of glutamine as a major change in metabolites for balancing the hyperosmotic stress [53].

\subsection{Precursors of the Osmoprotectant Glycine Betaine}

The level of ethanolamine in TG1-E1 exudates was increased by hyperosmotic stress (Table 4). Ethanolamine is a precursor of glycine betaine and proline which are two important osmoprotectants in plants [54]. In fact, exogenous application of ethanolamine stimulates glycine betaine biosynthesis in Nicotiana rustica, resulting in improved plant resistance to salt stress [55]. TG1-E1 up-regulated gene expression of Solyc07g008300 (Table 5), which is a choline monooxygenase functioning in the first step of glycine betaine biosynthesis [56]. TG1-E1 up-regulated gene expression of Solyc08g068600 (Table 5), a putative serine decarboxylase that is involved in ethanolamine metabolism. Meanwhile, the level of TG1-E1 exuded serine was increased by hyperosmotic stress (Table 4). Altogether, these results indicate that TG1-E1-produced ethanolamine may be utilized by the 
plants for glycine betaine production, thereby contributing to the bacteria-induced plant drought resistance.

\subsection{Pinitol}

An increase in the level of pinitol, a polyol that has been described as an osmoprotectant in several plant species [57-59], was also observed in TG1-E1 extracellular metabolites with the hyperosmotic stress treatment (Table 4). Synthesis of D-ononitol, a transient intermediate of D-pinitol, increased in leaves under drought stress conditions in Arabidopsis thaliana; subsequently, the D-ononitol was transported to the roots to synthesize D-pinitol, which then acts as osmoprotectant [58]. Therefore, pinitol produced by TG1-E1 may directly protect tomato roots from drought stress.

Together, these results potentially provide a mechanism for TG1-E1-induced plant drought resistance. It should be noted that in a real system, i.e., plants with root-colonizing bacteria, the dynamic interaction between the roots and the bacteria would likely result in more complex profiles of bacteria extracellular metabolites.

In this study, the plants were transferred from sterile growth medium to a steamsterilized $\left(20 \mathrm{~min}\right.$ at $\left.120^{\circ} \mathrm{C}\right)$ soil mixture of peat and vermiculite $(1: 1, v / v)$. The plants were then grown in a clean growth chamber. For performing the bacteria inoculation, the bacteria was centrifuged from its original culture solution and then resuspended in sterile $0.45 \% \mathrm{NaCl}$ solution. Although these actions could not completely prevent unwanted growth of other bacteria, they helped minimize possible involvements of other bacteria. Sometimes the inoculant may fail to colonize and consequently fail to trigger beneficial effects. However, it is unlikely that inoculation of one bacteria strain under these conditions would result in dominant growth of another strain, which then happens to cause the same beneficial effects to the plants. Nonetheless, our study of the soil-grown plants cannot completely exclude the possibility that certain environmental factors other than the inoculant may contribute to the plant-beneficial effects.

\section{Materials and Methods}

\subsection{Plant Materials and Growth Conditions}

Tomato (Solanum lycopersicum) seeds of two different cultivars, Micro-Tom and Ailsa Craig, were surface-sterilized by soaking in 5\% v/v sodium hypochlorite for $5 \mathrm{~min}$. After washing by sterile distilled water, the seeds were planted on 1/2-strength Murashige and Skoog medium $(0.5 \mathrm{MS})$ with $0.7 \%(w / v)$ agar and $1.5 \%(w / v)$ sucrose. The plates were then placed in the dark for $4 \mathrm{~d}$ at $25^{\circ} \mathrm{C}$. Seedlings were grown under sterile conditions with $200 \mu \mathrm{mol}$ photons $/ \mathrm{m} 2 / \mathrm{s}$ light, $25 \pm 2{ }^{\circ} \mathrm{C}$, at a $16 \mathrm{~h}$ light $/ 8 \mathrm{~h}$ dark cycle. Ten days after germination, tomato seedlings were transferred into a steam-sterilized $\left(20 \mathrm{~min}\right.$ at $\left.120{ }^{\circ} \mathrm{C}\right)$ soil mixture of peat and vermiculite $(1: 1, v / v)$. Plant growth and treatments took place in a growth chamber $\left(16 \mathrm{~h}\right.$ day at $25^{\circ} \mathrm{C}+8 \mathrm{~h}$ night at $\left.22^{\circ} \mathrm{C}\right)$.

\subsection{Bacterial Culture and Inoculation}

To make the inoculum, Bacillus megaterium TG1-E1 was cultured in liquid LuriaBertani (LB) medium at $37^{\circ} \mathrm{C}$ and $180 \mathrm{rpm}$ overnight. Bacterial growth was estimated by measuring the optical density at $600 \mathrm{~nm}$ using a spectrophotometer. The bacterial suspension was centrifuged (5000 rpm, $20 \mathrm{~min})$ and resuspended in $0.45 \%(w / v) \mathrm{NaCl}$ sterile solution. Inoculation with $B$. megaterium TG1-E1 was carried out 2 days after tomato seedlings were planting in 200-mL pots. Each seedling was grown in a separate pot and was inoculated with $50 \mathrm{~mL}$ bacterial suspension $\left(10^{8}-10^{9} \mathrm{CFU} / \mathrm{mL}\right)$ in $0.45 \% \mathrm{NaCl}$ sterile solution, and non-inoculated controls were watered with $0.45 \% \mathrm{NaCl}$ sterile solution.

\subsection{Monitoring of Plant Growth}

After 10 days of bacterial inoculation, the drought treatment was started by stopping the watering. Fresh weight (FW), relative water content (RWC), maximum chlorophyll fluorescence $(\mathrm{Fv} / \mathrm{Fm})$ and chlorophyll content of tomato seedlings were measured 
10 days after the drought treatment started. The RWC of the leaves was calculated as $\mathrm{RWC}=(\mathrm{FW}-\mathrm{DW}) \times(\mathrm{TW}-\mathrm{DW})-1$. The soil relative humidity was measured by a WET DELTA-T device (DELTA-T DEVICES LTD, Cambridge, England) at 1, 3 and 7 days after the drought treatment started, following the protocol provided by the manufacturer.

\subsection{Bacteria Root Colonization}

Root colonization test was carried out based on Vílchez et al. [60]. Briefly, TG1E1-inoculated and control tomato seedlings were harvest seven days after disruption of watering. Roots were separated from the aerial portions and were surface-sterilized by immersion in ethanol (75\%; vol/vol) for $1 \mathrm{~min}$, then washed for four times using sterile double-distilled water. Separated roots were then grinded using pistils in $1.5 \mathrm{~mL}$ tubes. A $0.45 \% \mathrm{NaCl}$ solution was used to prepare serial dilutions for a drop-by-drop seeding on LB agar plates. After $24 \mathrm{~h}$ culturing at $37^{\circ} \mathrm{C}$, bacteria colonies were counted and expressed as c.f.u. $\mathrm{mg}-1$ root dry weight.

\subsection{Quantification of Chlorophyll Contents and Photosynthesis Efficiency}

Two grams of fresh tomato leaves were immersed in $10 \mathrm{~mL}$ of $96 \%$ ethanol for $24 \mathrm{~h}$ at room temperature in the dark and then centrifuged at $5000 \mathrm{rpm}$ for $10 \mathrm{~min}$ at room temperature. The chlorophyll contents of the supernatants were measured by reading optical density (OD) using a Microplate Reader Thermo Varioskan Flash 13. The wave length for optical density measurements were 665 (OD665) and 649 (OD649) nm. The concentrations of total chlorophyll, chlorophyll $\mathrm{a}$, and chlorophyll $\mathrm{b}$ were calculated by the following equations:

Chlorophyll a concentration $(\mathrm{Ca})=13.95 \times$ OD665 $-6.88 \times$ OD649.

Chlorophyll b concentration $(\mathrm{Cb})=24.96 \times$ OD649 $-7.32 \times$ OD665.

Total chlorophyll concentration $(\mathrm{CT})=\mathrm{Ca}+\mathrm{Cb}$.

Content of chlorophyll $=(\mathrm{CT} \times \mathrm{V}) / \mathrm{W}$, where $\mathrm{V}$ is the volume of supernatant and $\mathrm{W}$ is the weight of fresh tissue.

The ratio of variable fluorescence/maximum fluorescence (Fv/Fm), which indicates the potential quantum yield of PSII photochemistry, was determined with a Fluorpen FP 100 (Photon Systems Instruments, Brno, Czech Republic) following the protocol provided by Photon Systems Instruments.

\subsection{Bacterial Extracellular Metabolite Collection and GC-MS Analysis}

Extraction of bacterial exudates under regular and hyperosmotic stress (by supplying $30 \% \mathrm{wt} / \mathrm{vol}$ of polyethyleneglycol; PEG-30; $24 \mathrm{~h}$ ) conditions, were prepared as in [53]. In brief, a $50 \mathrm{~mL}$ aliquot of a LB-cultured strain was filtered by a $22 \mu \mathrm{m}$ mesh, frozen at $-80{ }^{\circ} \mathrm{C}$ and freeze-dried for further processing. Then, $20 \mathrm{mg}$ per sample were treated with $80 \%$ methanol and $1 \mu \mathrm{M}$ of ribitol was added as an internal control. After being derivatized by using $100 \mu \mathrm{L}$ methoxylamine hydrochloride in pyridine and treated with $100 \mu \mathrm{L}$ MSTFA, samples were ready to be run in a TraceGC (up to $1 \mu \mathrm{L}$ per sample), coupled to a PolarisQ ion trap mass spectrometer (Thermo Finnigan, Dreieich, Germany). Compounds in the sample were separated on a $30 \mathrm{~m} \times 0.25 \mathrm{~mm}$ Equity- 5 column with $0.25 \mu \mathrm{m}$ coating of 5\% diphenyl 95\% dimethylsiloxane (Supelco, Bellefonte, California, CA, USA). Finally, compounds were identified by comparison with purified standards, the NIST 2005 database (NIST, Gaithersburg, MD, USA) and the Golm Metabolome Database. Identities were confirmed by matching mass spectral data and chromatographic retention time. Peak area quantification was prepared with Xcalibur 1.4 software (Thermo Finnigan, Dreieich, Germany) and normalized with ribitol standard and dry mass of the sample. Six replicates per condition were carried out in this analysis.

\subsection{RNAseq Analysis}

Tomato Micro-Tom cultivar was grown and treated as described in the "Plant growth conditions" section. TG1-E1-inoculated and control tomato seedlings were harvested 
7 days after disruption of watering. RNA was extracted by using Plant RNeasy Kit (Qiagen, Hilden, Germany), and the integrity was monitored using the RNA Nano 6000 Assay of the Agilent Bioanalyzer 2100 system (Agilent, Santa Clara, CA, USA). RNA purity and concentration were checked using a NanoDrop ND-1000 Spectrophotometer (NanoDrop Technologies, Wilmington, DE, USA).

RNAseq was performed at the Core Facility for Genomics, Shanghai Center for Plant Stress Biology, China. Three biological replicates of each treatment were generated. Total RNA $(1 \mu \mathrm{g})$ from each sample was used for library preparation with NEBNext Ultra Directional RNA Library Prep Kit for Illumina (New England Biolabs, E7420L), following the manufacturer's instructions. The prepared libraries were assessed for quality by using NGS High-Sensitivity Kit on a Fragment Analyzer (AATI) and for quantity by using Qubit 2.0 Fluorometer (Thermo Fisher Scientific).

For data analysis, SolexaQA 2.0 [61] and cutadapt v1.10 [62] were used to remove low quality regions and adapter sequences in the raw reads, and clean reads with length longer than $25 \mathrm{bp}$ and phred score greater than 17 were mapped to the Tair10 reference genome using TopHat 2.0.10 [63] with default parameters. The reads that were mapped to each annotated gene were counted by HTseq-count (version 0.9.1) [64]. Using edgeR [65], the raw counts of each gene were normalized, and differentially expressed genes were identified using fold change $>2$ and false discovery rate $<0.01$ as significance cutoffs. Three biological replicates of each condition were used to perform transcriptome analyses.

\subsection{Statistical Analysis}

Statistical analyses were performed with Prism software (https:/ /www.graphpad. $\mathrm{com} / \mathrm{scientific-software/prism/,} \mathrm{Accessed} 4$ April 2020). Significant difference between treatments was based on $p$-values $\leq 0.05$.

\section{Conclusions}

PGPR are promising tools for increasing crop drought resistance. In this study, we show that B. megaterium TG1-E1 increases drought resistance in different tomato cultivars. Our transcriptome analysis reveals several key mediators of TG1-E1-induced transcriptional regulation in tomato plants, including transcription factors, stress signaling components and regulators, and putative regulators of cell wall organization. In addition, our analysis of TG1-E1 extracellular metabolites identifies some important compounds, including sugars, amino acid, ethanolamine, and pinitol, which are potentially regulators (or precursors of regulators) of TG1-E1-triggered plant drought resistance. These findings not only contribute to our understanding of PGPR-triggered drought resistance in tomato plants, but also provide important clues for future elucidation of the underlying molecular mechanisms.

Supplementary Materials: The following are available online at https://www.mdpi.com/article/ 10.3390/metabo11060369/s1, Figure S1: Bacillus megaterium TG1-E1 alleviate drought stress and maintain growth in Ailsa-Craig tomato plants; Figure S2: Root colonization by TG1-E1 in tomato seedlings exposed to drought. Figure S3: Distribution of enriched Gene Ontology (GO). Supplementary Table S1: Differentially expressed genes (DEGs) regulated by TG1-E1 in drought stressed tomato plants (Micro-Tom) compared to un-inoculated plants. Excel files: Supplementary table Metabolites and Supplementary table RNAseq.

Author Contributions: H.Z. (Huiming Zhang) designed the project with the input of R.J.L.M. R.J.L.M., J.I.V. and S.Z. to-gether performed/participated in all experiments or data analysis. H.Z. (Hailing Zi) and R.L. performed R.N.A. seq raw data analysis. K.N. performed the G.C.-M.S. analysis. R.K. and D.H. participated in the experiments. H.Z. (Huiming Zhang) and R.J.L.M. wrote the manuscript with input from A.K.H. and J.I.V. All authors have read and agreed to the published version of the manuscript.

Funding: This research was funded by Chinese Academy of Sciences.

Institutional Review Board Statement: Not applicable. 
Informed Consent Statement: Not applicable.

Data Availability Statement: Data is contained within the article or Supplementary Material.

Acknowledgments: Research in H.Z. Lab has been supported by the Chinese Academy of Sciences (CAS).

Conflicts of Interest: The authors declare no conflict of interest.

\section{References}

1. Bailey-Serres, J.; Parker, J.E.; Ainsworth, E.A.; Oldroyd, G.E.D.; Schroeder, J.I. Genetic strategies for improving crop yields. Nature 2019, 575, 109-118. [CrossRef] [PubMed]

2. Zhu, J.K. Salt and drought stress signal transduction in plants. Annu. Rev. Plant Biol. 2002, 53, 247-273. [CrossRef]

3. Glick, B.R. Overview of plant growth-promoting bacteria. In Biochemical and Genetic Mechanisms Used by Plant Growth Promoting Bacteria; Patten, B.R.N., Holguin, G., Penrose, D.M., Eds.; Imperial College Press: London, UK, 1999; pp. 1-13.

4. Lugtenberg, B.; Kamilova, F. Plant-growth-promoting rhizobacteria. Annu. Rev. Microbiol. 2009, 63, 541-556. [CrossRef]

5. Liu, X.M.; Zhang, H. The effects of bacterial volatile emissions on plant abiotic stress resistance. Front. Plant. Sci. 2015, 6, 774. [CrossRef]

6. Amellal, N.; Burtin, G.; Bartoli, F.; Heulin, T. Colonization of wheat rhizosphere by EPS producing Pantoea agglomerans and its effect on soil aggregation. Appl. Environ. Microbiol. 1998, 64, 3740-3747. [CrossRef] [PubMed]

7. Zhang, H.; Sun, Y.; Xie, X.; Kim, M.S.; Dowd, S.E.; Paré, P.W. A soil iron via deficiency-inducible mechanisms. Plant J. 2009, 58, 568-577. [CrossRef]

8. Morcillo, R.J.L.; Singh, S.K.; He, D.; An, G.; Vílchez, J.I.; Tang, K.; Yuan, F.; Sun, Y.; Shao, C.; Zhang, S.; et al. Rhizobacteriumderived diacetyl modulates plant immunity in a phosphate-dependent manner. EMBO J. 2019, 39, e102602. [CrossRef]

9. Vílchez, J.I.; Tang, Q.; Kaushal, R.; Wang, W.; Lv, S.; He, D.; Chu, Z.; Zhang, H.; Liu, R.; Zhang, H. Complete Genome Sequence of Bacillus megaterium Strain TG1-E1, a Plant Drought Resistance-Enhancing Bacterium. Microbiol. Resour. Announc. 2018, 7, e00842-18. [CrossRef] [PubMed]

10. Yamaguchi-Shinozaki, K.; Shinozaki, K. Transcriptional regulatory networks in cellular responses and resistance to dehydration and cold stresses. Annu. Rev. Plant Biol. 2006, 57, 781-803. [CrossRef]

11. Huang, S.; Gao, Y.; Liu, J.; Peng, X.; Niu, X.; Fei, Z.; Cao, S.; Liu, Y. Genome-wide analysis of WRKY transcription factors in Solanum lycopersicum. Mol. Genet. Genom. 2012, 287, 495-513. [CrossRef] [PubMed]

12. Karkute, S.G.; Gujjar, R.S.; Rai, A.; Akhtar, M.; Singh, M.; Singh, B. Genome wide expression analysis of WRKY genes in tomato (Solanum lycopersicum) under drought stress. Plant Gene 2018, 13, 8-17. [CrossRef]

13. Niu, Y.; Zhao, T.; Xu, X.; Li, J. Genome-wide identification and characterization of GRAS transcription factors in tomato (Solanum lycopersicum). Peer]. 2017, 8, e3955. [CrossRef]

14. Castelán-Muñoz, N.; Herrera, J.; Cajero-Sánchez, W.; Arrizubieta, M.; Trejo, C.; García-Ponce, B.; Sánchez, M.; Álvarez-Buylla, E.R.; Garay-Arroyo, A. MADS-Box Genes Are Key Components of Genetic Regulatory Networks Involved in Abiotic Stress and Plastic Developmental Responses in Plants. Front. Plant Sci. 2019, 10, 853. [CrossRef]

15. Wu, J.; Wang, J.; Pan, C.; Guan, X.; Wang, Y.; Liu, S.; He, Y.; Chen, J.; Chen, L.; Lu, G. Genome-wide identification of MAPKK and MAPKKK gene families in tomato and transcriptional profiling analysis during development and stress response. PLoS ONE 2014, 18, e103032. [CrossRef]

16. Xiong, L.; Schumaker, K.S.; Zhu, J.-K. Cell Signaling during Cold, Drought, and Salt Stress. Plant Cell 2002, 14, S165-S183. [CrossRef]

17. Wan, D.; Li, R.; Zou, B.; Zhang, X.; Cong, J.; Wang, R.; Xia, Y.; Li, G. Calmodulin-binding protein CBP60g is a positive regulator of both disease resistance and drought resistance in Arabidopsis. Plant Cell Rep. 2012, 31, 1269-1281. [CrossRef]

18. Perez-Prat, E.; Narashimhan, M.L.; Binzel, M.L.; Botella, M.A.; Chen, Z.; Valpuesta, V.; Bressan, R.A.; Hasegawa, P.M. Induction of aputative $\mathrm{Ca}^{2+}$-ATPase mRNA in $\mathrm{NaCl}$ adapted cells. Plant Physiol. 1992, 100, 1471-1478. [CrossRef] [PubMed]

19. Wimmers, L.E.; Ewing, N.N.; Bennett, A.B. Higher plant $\mathrm{Ca}^{2+}$ ATPase: Primary structure and regulation of mRNA abundance by salt. Proc. Natl. Acad. Sci. USA 1992, 89, 9205-9209. [CrossRef]

20. Huda, K.M.; Banu, M.S.; Garg, B.; Tula, S.; Tuteja, R.; Tuteja, N. OsACA6, a P-type IIB Ca ${ }^{2+}$ ATPase promotes salinity and drought stress resistance in tobacco by ROS scavenging and enhancing the expression of stress-responsive genes. Plant J. 2013, 76, 997-1015. [CrossRef] [PubMed]

21. Rudrappa, T.; Czymmek, K.J.; Paré, P.W.; Bais, H.P. Root-secreted malic acid recruits beneficial soil bacteria. Plant Physiol. 2008, 148, 1547-1556. [CrossRef]

22. Rekha, K.; Baskar, B.; Srinath, S.; Usha, B. Plant-growth-promoting rhizobacteria Bacillus subtilis RR4 isolated from rice rhizosphere induces malic acid biosynthesis in rice roots. Can. J. Microbiol. 2018, 64, 20-27. [CrossRef]

23. Tenhaken, R. Cell wall remodeling under abiotic stress. Front. Plant Sci. 2015, 7, 771. [CrossRef]

24. Le Gall, H.; Philippe, F.; Domon, J.M.; Gillet, F.; Pelloux, J.; Rayon, C. Cell Wall Metabolism in Response to Abiotic Stress. Plants 2015, 16, 112. [CrossRef]

25. Lakshmanan, V.; Castaneda, R.; Rudrappa, T.; Bais, H.P. Root transcriptome analysis of Arabidopsis thaliana exposed to beneficial Bacillus subtilis FB17 rhizobacteria revealed genes for bacterial recruitment and plant defense independent of malate efflux. Planta 2013, 238, 657-668. [CrossRef] 
26. Piro, G.; Leucci, M.R.; Waldron, K.; Dalessandro, G. Exposure to water stress causes changes in the biosynthesis of cell wall polysaccharides in roots of wheat cultivars varying in drought resistance. Plant Sci. 2003, 165, 559-569. [CrossRef]

27. Lairson, L.L.; Henrissat, B.; Davies, G.J.; Withers, S.G. Glycosyltransferases: Structures, functions, and mechanisms. Annu. Rev. Biochem. 2008, 77, 521-555. [CrossRef]

28. Ding, X.; Li, J.; Pan, Y.; Zhang, Y.; Ni, L.; Wang, Y.; Zhang, X. Genome-wide identification and expression analysis of the UGlcAE gene family in tomato. Int. J. Mol. Sci. 2018, 19, 1583. [CrossRef]

29. Takenaka, Y.; Kato, K.; Ogawa-Ohnishi, M.; Tsuruhama, K.; Kajiura, H.; Yagyu, K.; Takeda, A.; Takeda, Y.; Kunieda, T.; HaraNishimura, I.; et al. Pectin RG-I rhamnosyltransferases represent a novel plant-specific glycosyltransferase family. Nat. Plants 2018, 4, 669-676. [CrossRef] [PubMed]

30. Lee, C.; Teng, Q.; Zhong, R.; Yuan, Y.; Haghighat, M.; Ye, Z.H. Three Arabidopsis DUF579 domain-containing GXM proteins are methyltransferases catalyzing 4-o-methylation of glucuronic acid on xylan. Plant Cell Physiol. 2012, 53, 1934-1949. [CrossRef] [PubMed]

31. Beauregard, P.B.; Chai, Y.; Vlamakis, H.; Losick, R.; Kolter, R. Bacillus subtilis biofilm induction by plant polysaccharides. Proc. Natl Acad. Sci. USA 2013, 110, E1621-E1630. [CrossRef] [PubMed]

32. Das, P.K.; Biswas, R.; Anjum, N.; Das, A.K.; Maiti, M.K. Rice matrix metalloproteinase OsMMP1 plays pleiotropic roles in plant development and symplastic-apoplastic transport by modulating cellulose and callose depositions. Sci. Rep. 2018, 8, 2783. [CrossRef]

33. Vílchez, J.I.; García-Fontana, C.; Román-Naranjo, D.; González-López, J.; Manzanera, M. Plant drought resistance enhancement by trehalose production of desiccation-tolerant microorganisms. Front. Microbiol. 2016, 7, 1577. [CrossRef]

34. Iordachescu, M.; Imai, R. Trehalose biosynthesis in response to abiotic stresses. J. Integr. Plant Biol. 2008, 50, 1223-1229. [CrossRef]

35. Jain, N.K.; Roy, I. Effect of trehalose on protein structure. Protein Sci. 2009, 18, 24-36. [CrossRef] [PubMed]

36. Jiang, H.; Liu, G.L.; Chi, Z.; Hu, Z.; Chi, Z.M. Genetics of trehalose biosynthesis in desert-derived Aureobasidium melanogenum and role of trehalose in the adaptation of the yeast to extreme environments. Curr. Genet. 2018, 64, 479-491. [CrossRef] [PubMed]

37. Chenu, C.; Roberson, E.B. Diffusion of glucose in microbial extracellular polysaccharide as affected by water potential. Soil Biol. Biochem. 1996, 28, 877-884. [CrossRef]

38. Sandhya, V.; Ali, S.Z. The production of exopolysaccharide by Pseudomonas putida GAP-P45 under various abiotic stress conditions and its role in soil aggregation. Microbiology 2015, 84, 512-519. [CrossRef]

39. Vardharajula, V.; Ali, S.Z.; Grover, M.; Reddy, G.; Bandi, V. Drought-tolerant plant growth promoting Bacillus spp.: Effect on growth, osmolytes, and antioxidant status of maize under drought stress. J. Plant Interact. 2011, 6, 1-14. [CrossRef]

40. ElSayed, A.I.; Rafudeen, M.S.; Golldack, D. Physiological aspects of raffinose family oligosaccharides in plants: Protection against abiotic stress. Plant Biol. 2014, 16, 1-8. [CrossRef] [PubMed]

41. Alcázar, R.; Marco, F.; Cuevas, J.C.; Patron, M.; Ferrando, A.; Carrasco, P.; Tiburcio, A.F.; Altabella, T. Involvement of polyamines in plant response to abiotic stress. Biotechnol. Lett. 2006, 28, 1867-1876. [CrossRef]

42. Takahashi, T.; Kakehi, J.I. Polyamines: Ubiquitous polycations with unique roles in growth and stress responses. Ann. Bot. 2010, 105, 1-6. [CrossRef] [PubMed]

43. Shi, H.; Chan, Z. Improvement of plant abiotic stress tolerance through modulation of the polyamine pathway. J. Integr. Plant Biol. 2014, 56, 114-121. [CrossRef] [PubMed]

44. Ghosh, D.; Sen, S.; Mohapatra, S. Modulation of proline metabolic gene expression in Arabidopsis thaliana under water-stressed conditions by a drought-mitigating Pseudomonas putida strain. Ann. Microbiol. 2017, 67, 655-668. [CrossRef]

45. Sen, S.; Ghosh, D.; Mohapatra, S. Modulation of polyamine biosynthesis in Arabidopsis thaliana by a drought mitigating Pseudomonas putida strain. Plant Physiol. Biochem. 2018, 129, 180-188. [CrossRef]

46. Rastogi, R.; Dulson, J.; Rothstein, S.J. Cloning of tomato (Lycopersicon esculenfum Mill.) Arginine decarboxylase gene and its expression during fruit ripening. Plant Physiol. 1993, 103, 829-834. [CrossRef]

47. Urano, K.; Yoshiba, Y.; Nanjo, T.; Igarashi, Y.; Seki, M.; Sekiguchi, F.; Yamaguchi-Shinozaki, K.; Shinozaki, K. Characterization of Arabidopsis genes involved in biosynthesis of polyamines in abiotic stress responses and developmental stages. Plant. Cell Environ. 2003, 26, 1917-1926. [CrossRef]

48. Kakkar, R.K.; Sawhney, V.K. Polyamine research in plants-A changing perspective. Physiol. Plant. 2002, 116, 281-288. [CrossRef]

49. Sinha, R.; Rajam, M.V. RNAi silencing of three homologues of S-adenosylmethionine decarboxylase gene in tapetal tissue of tomato results in male sterility. Plant Mol. Biol. 2013, 82, 169-180. [CrossRef]

50. Liu, Q.; Kasuga, M.; Sakuma, Y.; Abe, H.; Miura, S.; Yamaguchi-Shinozaki, K.; Shinozaki, K. Two transcription factors, DREB1 and DREB2, with an EREBP/AP2 DNA binding domain separate two cellular signal transduction pathways in drought- and low-temperature-responsive gene expression, respectively, in Arabidopsis. Plant Cell 1998, 10, 1391-1406. [CrossRef]

51. Jeong, J.S.; Kim, Y.S.; Redillas, M.C.; Jang, G.; Jung, H.; Bang, S.W.; Choi, Y.D.; Ha, S.H.; Reuzeau, C.; Kim, J.K. OsNAC5 overexpression enlarges root diameter in rice plants leading to enhanced drought resistance and increased grain yield in the field. Plant Biotechnol. J. 2013, 11, 101-114. [CrossRef]

52. Kan, C.C.; Chung, T.Y.; Juo, Y.A.; Hsieh, M.H. Glutamine rapidly induces the expression of key transcription factor genes involved in nitrogen and stress responses in rice roots. BMC Genom. 2015, 16, 731. [CrossRef] [PubMed] 
53. Vílchez, J.I.; Niehaus, K.; Dowling, D.N.; González-López, J.; Manzanera, M. Protection of pepper plants from drought by Microbacterium sp. 3J1 by modulation of the plant's glutamine and a-ketoglutarate content: A comparative metabolomics approach. Front. Microbiol. 2018, 9, 284. [CrossRef] [PubMed]

54. Igamberdiev, A.U.; Kleczkowski, L.A. The glycerate and phosphorylated pathways of serine synthesis in plants: The branches of plant glycolysis linking carbon and nitrogen metabolism. Front. Plant Sci. 2018, 9, 318. [CrossRef]

55. Rajaeian, S.; Ehsanpour, A.A.; Javadi, M.; Shojaee, B. Ethanolamine induced modification in glycine betaine and proline metabolism in Nicotiana rustica under salt stress. Biol. Plant. 2017, 61, 797-800. [CrossRef]

56. Bhuiyan, N.H.; Hamada, A.; Yamada, N.; Rai, V.; Hibino, T.; Takabe, T. Regulation of betaine synthesis by precursor supply and choline monooxygenase expression in Amaranthus tricolor. J. Exp. Bot. 2007, 58, 4203-4212. [CrossRef]

57. Streeter, J.G.; Lohnes, D.G.; Fioritto, R.J. Patterns of pinitol accumulation in soybean plants and relationships to drought resistance. Plant Cell Environ. 2001, 24, 429-438. [CrossRef]

58. Ahn, C.H.; Hossain, M.D.; Lee, E.; Kanth, B.K.; Park, P.B. Increased salt and drought resistance by D-pinitol production in transgenic Arabidopsis thaliana. Biochem. Biophys. Res. Commun. 2018, 504, 315-320. [CrossRef]

59. Gargallo-Garriga, A.; Preece, C.; Sardans, J.; Oravec, M.; Urban, O.; Peñuelas, J. Root exudate metabolomes change under drought and show limited capacity for recovery. Sci. Rep. 2018, 8, 12696. [CrossRef]

60. Vílchez, J.I.; Yang, Y.; Yi, D.; Zhang, H. Measurements of root colonized bacteria species. Bio-Protoc. 2021,11 , e3976.

61. Cox, M.P.; Peterson, D.A.; Biggs, P.J. SolexaQA: At-a-glance quality assessment of Illumina second-generation sequencing data. BMC Bioinform. 2010, 11, 485. [CrossRef]

62. Martin, M. Cutadapt removes adapter sequences from high-throughput sequencing reads. EMBnet J. 2011, 17, 10-12. [CrossRef]

63. Trapnell, C.; Pachter, L.; Salzberg, S.L. TopHat: Discovering splice junctions with RNA-Seq. Bioinformatics 2009, $25,1105-1111$. [CrossRef] [PubMed]

64. Anders, S.; Pyl, P.T.; Huber, W. HTSeq-A Python framework to work with high-throughput sequencing data. Bioinformatics 2015, 31, 166-169. [CrossRef] [PubMed]

65. Robinson, M.D.; McCarthy, D.J.; Smyth, G.K. edgeR: A Bioconductor package for differential expression analysis of digital gene expression data. Bioinformatics 2010, 26, 139-140. [CrossRef] [PubMed] 